\title{
ECOLOGICAL IMPACT OF HISTORICAL LAND-USE PATTERNS IN THE GREAT PLAINS: A METHODOLOGICAL ASSESSMENT
}

\author{
William J. Parton, ${ }^{1,3}$ Myron P. Gutmann, ${ }^{2}$ Stephen A. Williams, ${ }^{1}$ Mark Easter, ${ }^{1}$ And Dennis Ojima ${ }^{1}$ \\ ${ }^{1}$ Natural Resource Ecology Laboratory, Colorado State University, Fort Collins, Colorado 80523-1499 USA \\ ${ }^{2}$ Inter-university Consortium for Political and Social Research, Population Studies Center, Department of History, \\ University of Michigan, P.O. Box 1248, Ann Arbor, Michigan 48104 USA
}

\begin{abstract}
This paper demonstrates a method for using historical county-level agricultural land-use data to drive an ecosystem model. Four case study counties from the U.S. Great Plains during the 19th and 20th centuries are used to represent different agroecosystems. The paper also examines the sensitivity of the estimates of county-level ecosystem properties when using different levels of detail in the land-use histories. Using weighted averages of multiple-model runs for grassland, dryland cropping, and irrigated cropping improved prediction over a simple, single-run approach that models the prevailing land use. Model runs with the same land use and environment generally reach similar levels of soil carbon and nitrogen mineralization after $\sim 50$ years, no matter when they began, with faster convergence for irrigated cropland. Model results show that cultivation of grasslands results in large losses of soil carbon and an increase in soil nitrogen mineralization for the first 20-30 years of cultivation, which is followed by low soil carbon loss and nitrogen mineralization 50 years after cultivation started. The recently observed increase in irrigated agriculture in the central and northern Great Plains (2.7 million ha) has resulted in a net carbon storage of $21.3 \mathrm{Tg}$ carbon, while irrigated cotton production has resulted in a net loss of $12.1 \mathrm{Tg}$ carbon.
\end{abstract}

Key words: agriculture; Great Plains, USA; land-use change; modeling; nitrogen cycling; soil carbon.

\section{INTRODUCTION}

In recent years, scientists have expressed considerable interest in understanding the impact of historical land-use patterns on natural and managed ecosystems (Ojima et al. 1993, Houghton 1994, Ramankutty and Foley 1999, Parton et al. 2003, Palm et al. 2005). Specifically, there is interest in how changes in land use have shaped the carbon budget, trace gas fluxes, and nutrient cycling, as well as the overall sustainability of ecosystems at local, regional, and global scales (Matson et al. 1997, Del Grosso et al. 2002a, b). This interest is driven by concern regarding the impact of anthropogenic activities on greenhouse gas fluxes and the impact of greenhouse gas concentrations on the global climate system. This scientific concern has led to numerous efforts to quantify historical land-use patterns at regional and global scales. Newly available historical land-use data are being used to drive ecosystem models capable of simulating changes in ecosystem dynamics resulting from observed historical land-use patterns.

The historical land-use data needed to drive ecosystem models in the Great Plains include information about temporal changes in crop rotations, tillage prac-

Manuscript received 10 September 2004; revised 25 February 2005; accepted 3 March 2005; final version received 29 April 2005. Corresponding Editor: J. M. Stark.

${ }^{3}$ E-mail: billp@nrel.colostate.edu tices, inorganic and organic fertilizer additions, crop yields, crop harvesting practices, crop varieties, and planting and harvesting dates. This type of information is available in electronic format for dates after about 1960 , but the information for dates prior to 1960 is much less complete, difficult to compile, and is not generally available. A number of research groups are attempting to collate this type of historical land-use data at regional and global scales and in a consistent electronic format so it can be used to drive ecosystem simulation models (Ramankutty and Foley 1999). The U.S. Agriculture Census Data contains many of the elements required for this purpose beginning as early as 1850; similar databases exist for historical land-use patterns in Europe and other developed countries, while there are less informative data for most other locations.

The primary goal of this paper is to demonstrate how detailed land-use data can be linked to ecological models and then to evaluate the sensitivity of those model results to different levels of information about temporal changes in historical and dominant land-use practices. Specifically, we link the CENTURY Agroecosystem Model (Parton et al. 1993) to detailed land-use data from four counties in the U.S. Great Plains (Hamilton, Nebraska; Pawnee, Kansas; Hockley, Texas; and Ramsey, North Dakota). The land-use data are primarily derived from U.S. Agricultural Census Data, available on a 5- to 10-year basis since the 1870 s, and are maintained in the Great Plains Population and Environment 
FIG. 1. Simplified flow diagram for the CENTURY model. Abbreviations for factors controlling model flows are: S, senescence; $\mathrm{P}$, precipitation; $\mathrm{T}$, air temperature; $\mathrm{SOM}$, soil organic matter; and DEFAC, abiotic decomposition rate. Arrows with dashed lines represent information flows, and arrows with solid lines are mass flows.

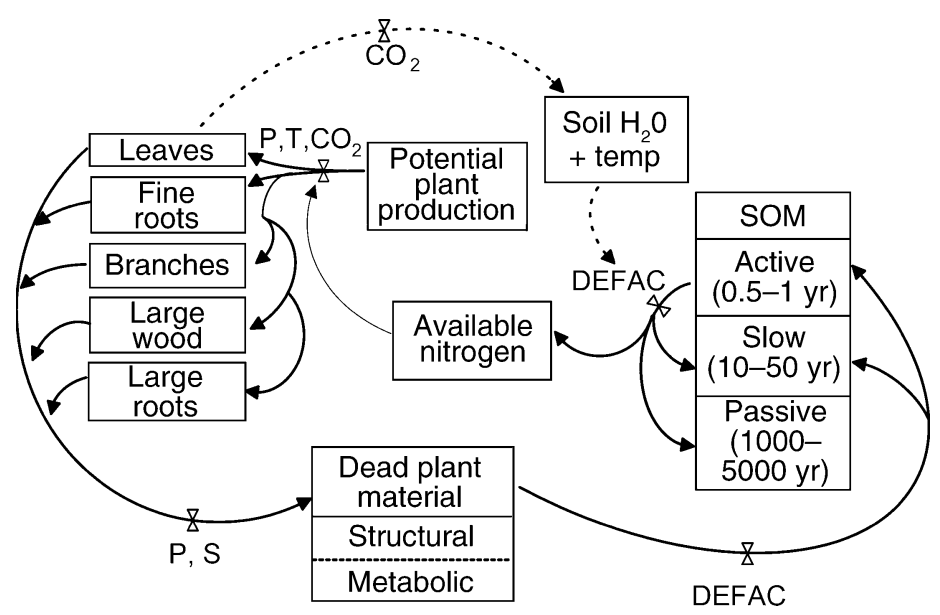

Database (Gutmann et al. 1998, Gutmann 2000; available online) ${ }^{4}$ The selected counties represent a variety of land-use patterns in the Great Plains, including dryland agriculture, irrigated agriculture, grazing, and the implementation of the Conservation Reserve Program (CRP) on land previously used for other purposes (Mitchell 1988).

The U.S. Agricultural Census Data contain countylevel information about planted and harvested acreage and production for major crops, as well as acreage devoted to grazing and total farmland. Additional information, including the economic value of harvested crops and other products, numbers of livestock, and land in soil conservation programs is also available. We used other data sources for information about temporal changes in inorganic fertilizer levels for different crops (Skinner 1931, Ross and Mehring 1938, USDA 1938, 1946, 1954, 1966, Smalley et al. 1939, Ibach et al. 1964, Ibach and Adams 1967, Alexander and Smith 1990, ERS 1994, 2003, NRIAI 2003), and descriptions of dominant crop rotations (Chilcott 1907, Spillman 1908, Briggs and Belz 1910, Kezer 1917, Piper et al. 1924, Wooten 1924, Sewell and Call 1925, Steinel 1926, Hardies and Hume 1927, Bonnen and Rogers 1928, Ellsworth 1929, Rogers and Elliott 1929, Hodges et al. 1930, Bonnen and Elliott 1931, von Trebra and Wagner 1932, Elliott 1933, Hargreaves 1993, Hurt 1994, NRI 1997, CTIC 1998, Miner 1998, Brenner et al. 2002). The crop rotation data include information about tillage practices, crop varieties, planting and harvest dates, crop harvest practices, and organic fertilizer application for the dominant crop rotations used in the United States during the last 150 years.

These detailed land-use data were used to develop CENTURY model schedule files that describe year-toyear changes in agricultural land use during the last 150 years. CENTURY model land-use schedule files were developed for dryland agriculture, irrigated agriculture, grazing land and CRP land, and were applied

\footnotetext{
${ }^{4}\langle$ http://www.icpsr.umich.edu/plains $\rangle$
}

to each county. For this paper, CENTURY model runs were designed to simulate changes in nitrogen mineralization and soil carbon levels resulting from historical land-use practices. Model runs were also designed to assess the sensitivity of ecosystem dynamics (soil carbon and nitrogen mineralization) to the degree of detail used to represent observed temporal changes in land-use patterns and the number of cropping systems used to represent ecosystem dynamics. This approach was designed to answer a series of specific methodological questions, which we will explain, along with the approach we used to answer them.

\section{CENTURY model description}

CENTURY is a generalized ecosystem model that simulates the dynamics of carbon $(\mathrm{C})$, nitrogen $(\mathrm{N})$, and phosphorus in grassland, forest, savanna, and crop systems (Metherell et al. 1993, Parton et al. 1993). The model includes plant production, nutrient cycling, water flow, and soil organic matter submodels (Fig. 1). The plant production and water flow models use monthly time steps, while the nutrient cycling and soil organic matter submodels use weekly time steps. Observed monthly precipitation and average daily maximum and minimum temperatures are the major abiotic drivers for the model. Soil texture, bulk density, soil depth, soil field capacity, and wilting point are the major soil input variables. The model has been well tested using observed plant production, soil organic matter, and nutrient cycling data from crop, grassland, and forest systems (Parton et al. 1993, Parton and Rasmussen 1994, Kelly et al. 1997). The cropping system and grassland components of CENTURY have been tested extensively, showing that the model can correctly simulate the impact of different cultivation practices (Metherell et al. 1995), cropping systems (Kelly et al. 1997), and organic and inorganic fertilizer applications (Paustian et al. 1992) on observed changes in soil C and $\mathrm{N}$ levels, soil nitrogen mineralization, and crop yields.

The CENTURY model calculates potential plant production and nutrient uptake as a function of soil water 
stress, leaf area index, and soil temperature, and then limits plant production based on soil nutrient availability. Soil nutrients are mineralized as a result of decomposition of dead plant material and soil organic matter pools. The soil organic matter submodel includes dead plant material and three soil organic matter pools (active, slow, and passive). A complete description of the structure of the CENTURY model and the equations used to describe carbon and nutrient flows are presented by Parton et al. (1993). Soil C and N, and $\mathrm{N}$ mineralization rates, represent values for the 0 $20 \mathrm{~cm}$ soil depth.

The CENTURY model is designed to represent the impact of land-use changes on ecosystem dynamics. To accomplish this, it makes use of schedule files that define the land use and management practices for each month of the year during the time period (retrospective or prospective) for which the model is run. The model has a software package (Metherell et al. 1993) that allows the model user to define timing of different landuse management practices and includes a library of crop tillage practices, inorganic and organic fertilizer amounts, harvest practices, tree removal practices, tree and grass burning practices, and different crops, trees, and grasses. For example, the user can specify the crop to be grown, the planting date of the crop, tillage events, fertilizer applications, and types of harvest for the crop. The CENTURY model has been parameterized for the major crops, grasses, and trees grown in the world and can be easily adjusted to represent them specifically at a given site by creating a new crop, grass, or tree to be included in the library. The next section of the paper will discuss how the Great Plains landuse data were collected and give examples of how the data were used to construct CENTURY schedule files (crop management files).

The U.S. Agriculture Census Data for the four counties report area harvested and production, allowing us to calculate county-level crop yield data for the major crops (corn, wheat, and cotton). Because separate yields for irrigated and nonirrigated land are not generally available, estimated crop yields were calculated by weighting the simulated crop yields for the dryland and irrigated runs based on the fraction of the total observed harvested area that was either irrigated or dryland and then compared with the observed total county crop yield. These data were used to test CENTURY model-simulated crop yields for corn, wheat, and cotton for the four counties during the last 100 years. Fig. 2 shows the comparison of observed and simulated corn yields for Nebraska and wheat yields for Kansas. The model results compare well with the observed yield data, and they show the observed pattern of low yields prior to 1940 and increasing yields from 1940 to 1980. An aggregated comparison of simulated and observed crop yields for all of the counties show that $r^{2}=0.92, r^{2}=0.38$, and $r^{2}=0.37$, respectively, for corn, wheat, and cotton.
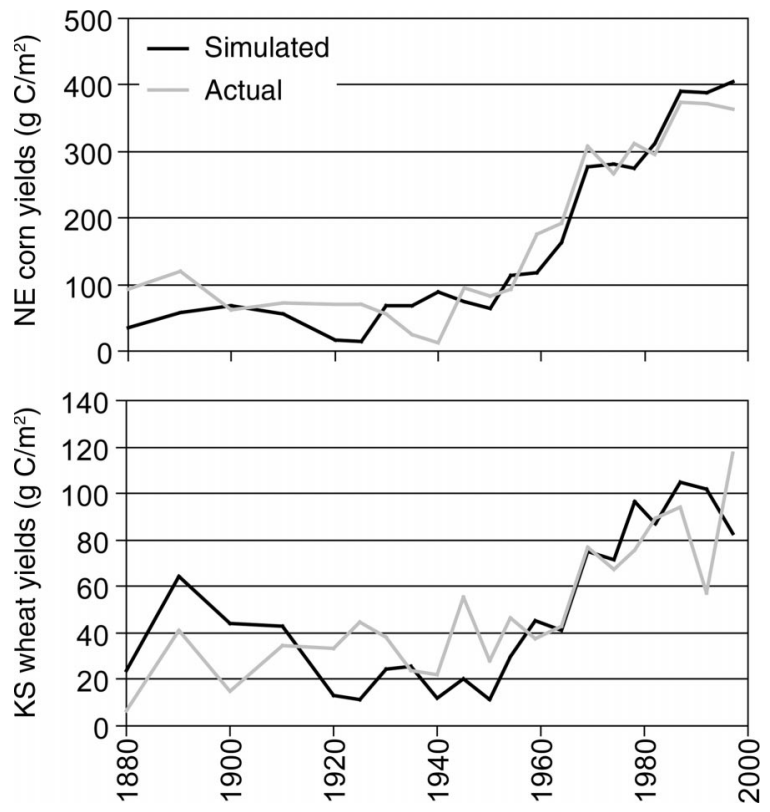

FIG. 2. Comparison of simulated vs. observed (a) corn yield in Hamilton County, Nebraska (NE), and (b) wheat yields for Pawnee County, Kansas (KS), USA, for the years $1880-1996$.

\section{Land-use change data}

The primary data for describing land-use change come from the U.S. Agricultural Census tabulations from 1850 to 1997 . In order to achieve successful results in both our models and in our interpretation of the historical record, we made a number of simplifying assumptions. These assumptions allowed us to present a stylized view of past land use and environmental change while still preserving the broad outlines of real experience. This paper tests the accuracy of the estimates made by the CENTURY model with specific data (see Fig. 2), and evaluates different strategies for designing model runs.

Our stylized view of the transformation of agricultural land use over time implies a series of transitions from certain patterns of land cover/land use from the mid-19th century until the present. We assume, first, that all the land in our study counties was initially covered in native grasses. Some time after that, European settlement began, and over some period of time (generally 20-50 years), native grasses were plowed up and dryland crops were planted. Later, irrigation was introduced, generally, but not always, to replace dryland cropping. Finally, some land in dryland cropping was converted back to grassland through CRP.

The data available from the agricultural censuses give us sufficient detail to understand the processes just described. Every ten years from 1870 until 1920, and roughly every five years since, the census records the amount of land harvested by crop, which can be summed to total cropland. In most years, the amount 
of cropland harvested is also divided into irrigated and nonirrigated land, so that we could separate irrigated cropland from dryland cropland. Finally, beginning with the 1987 Census of Agriculture, the amount of land in each county contracted to CRP is listed.

One of the most important assumptions we made is that, in each county, there is a single dominant cropping structure and rotation at any given time. For example, while we may know the distribution of cropped acreage within a county among a variety of crops (say corn, wheat, sorghum, hay, etc.), we represent all the dryland acreage in a county with a single set of crops and rotations. In other words, we have performed our analysis based on the assumption that all the dryland agriculture within a county operated in one way, and all the irrigated agriculture in a different way, even if we know that there was some diversity of practices between farms, or even on a single farm. We used the observed farming practices, which have changed over time, implying that the single set of dryland farming practices may have been different in 1920 from 1940 or 1960 . Beyond that, the most important assumptions we made about the land-use data are the following: (1) Total land in pasture was equal to the difference between total cropland and total land in the county. (2) The dryland cropping area was equal to the difference between total cropland and land in irrigated production.

Fig. 3 shows the changes in land area in irrigated, dryland, pastureland, and CRP land during the last 150 years for the four counties. For Hamilton County, Nebraska, most of the plow-out of grassland occurred during the 20 years from 1870 to 1890 . There was a large increase in irrigation from 1950 to 1980 , and a trivial amount of CRP land. The increase in irrigated land primarily came from dryland cropping because the grassland area changed little from 1950 to 1980 . The Pawnee County, Kansas, data show that the major grassland plow-out started in 1880 and continued until 1930. Irrigation did not start until 1960, with most of the irrigated land coming out of dryland cropping. There was a substantial amount of dryland cropping that transitioned into CRP land during the 1980s and 1990s. Hockley, Texas, represents the southern Great Plains, where plow-out of grasslands started in 1925 and was almost complete by 1950 . Irrigation of cotton, the main crop in Hockley, began in 1940, increased to its maximum land area by 1960 , and primarily came from grassland. Grassland area decreased, while dryland cropping remained fairly constant from 1940 to 1970. Ramsey, North Dakota, represents the northern Great Plains, where the plow-out of grassland primarily occurred from 1880 to 1920 ; there has been minimal irrigated cropping and $<5 \%$ of the land has been converted to CRP. Unfortunately, the agricultural census data does not specifically allow us to determine prior land use when large land areas are added to new land uses such as the irrigated land added during the 1960s and 1970s. In some cases, we can draw strong infer-

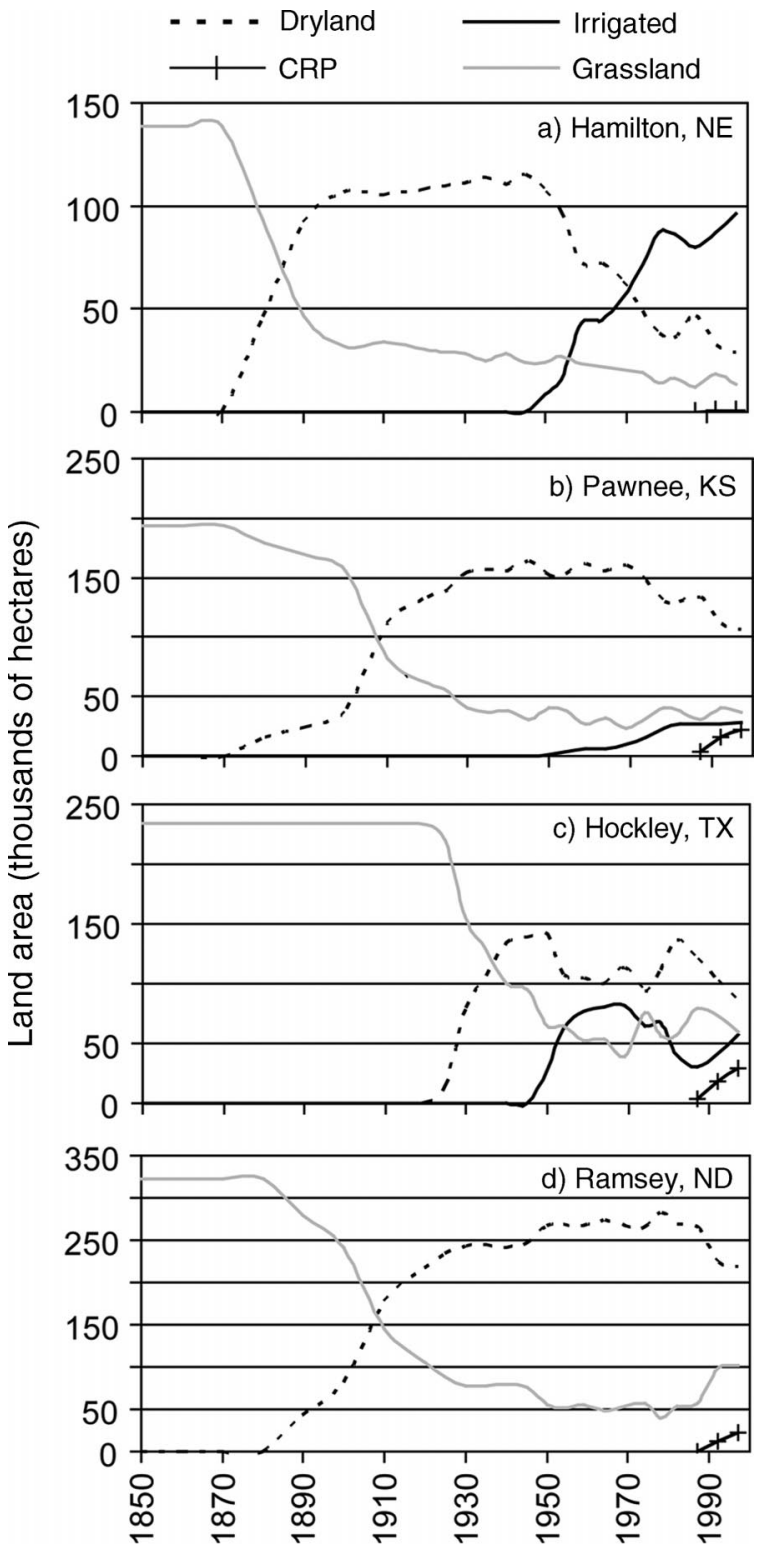

FIG. 3. Observed changes in county land area for dryland crops, irrigated crops, grassland, and Conservation Reserve Program (CRP) for (a) Hamilton, Nebraska (NE), (b) Pawnee, Kansas (KS), (c) Hockley, Texas (TX), and (d) Ramsey, North Dakota (ND).

ences about the prior land use, such as the Hamilton, Nebraska, data showing that irrigated land came from dryland cropping, while in Pawnee, Kansas, it is more difficult to determine the prior land use of the added irrigated land.

In recent years, each county has had a distinctive cropping pattern. In Hamilton County, Nebraska, the primary crops are winter wheat and corn with both crops planted annually because there is sufficient rainfall. Dryland winter wheat and corn were dominant prior to 1950 , but irrigated corn is currently the dom- 
inant cropping system. In Pawnee County, Kansas, the primary crops are dryland winter wheat, using both wheat/fallow and continuous wheat-cropping systems. Sorghum and cotton are grown in Hockley County, Texas, with irrigated cotton being the dominant crop at the present time. In Ramsey County, North Dakota, the primary crops are spring wheat grown in both wheat/fallow and continuous wheat-cropping systems.

The information on historical cropping practices used for the four county CENTURY simulations was gathered from a variety of sources with differing scales of coverage that ranged from the experience of a single farmer (Miner 1998) to the information recorded in national databases (NASS 1995-1999). The goal was to gain as much knowledge as possible from the time of plow-out and the "pioneer" stage of subsistence farming until modern farming regions and practices. Information on individual crops and early crop rotations was gathered from literature dating as far back as the horse-drawn era of the late 1880s (Shelton et al. 1889, Georgeson et al. 1890, Spillman 1902, 1905, Clark 1904, Carleton 1914) through the emergence and eventual dominance of today's technologies (Chilcott 1910, Leighty 1938, Kifer et al. 1940, Haas and Evans 1957, Bogue 1963, Cochrane 1993, Hargreaves 1993, Hurt 1994, NRI 1997, CTIC 1998, Miner 1998, Sisk 1998, USDA FSA 2000, Brenner et al. 2002, NRIAI 2003). Data were also accumulated on the changing use of manure and inorganic fertilizers (Brooks 1901, Anonymous 1924, Fraps and Asbury 1931, Skinner 1931, Ross and Mehring 1938, Salter and Schollenberger 1938, USDA 1938, 1946, 1954, 1966, Smalley et al. 1939, Ibach et al. 1964, Ibach and Adams 1967, Alexander and Smith 1990, ERS 1994, 2003, Lander and Moffitt 1996, NRIAI 2003). Many early studies of cropping systems by region were investigated (Holmes 1903, Warren 1911, Smith 1912, Kezer 1917, Wallace and Bressman 1923, Sewell and Call 1925, Steinel 1926, Bonnen and Rogers 1928, Elliott and Tapp 1928, Ellsworth 1929, Hodges et al. 1930, Bonnen and Elliott 1931, Throckmorton and Duley 1935, Matthews and Cole 1938). One such study by Elliott (1933), subdivided the United States into 14 major farm types and over 500 subregions. These databases were used to construct CENTURY schedule files that describe changes in crop rotations, tillage practices, crop varieties, harvest practices, and fertilizer inputs by time period for the state level major land resource area (MLRA) regions in the United States (USDA SCS 1981). From this universe of background information, we constructed CENTURY schedule files for the dominant irrigated and dryland crop rotation in each of the four counties for the current CENTURY model runs.

These historical farming practices were used to design four CENTURY schedule files for each county, each representing the record of farming practices for one of the four land-use practices: grassland, dryland cropping, irrigated cropping, and CRP. In effect, we

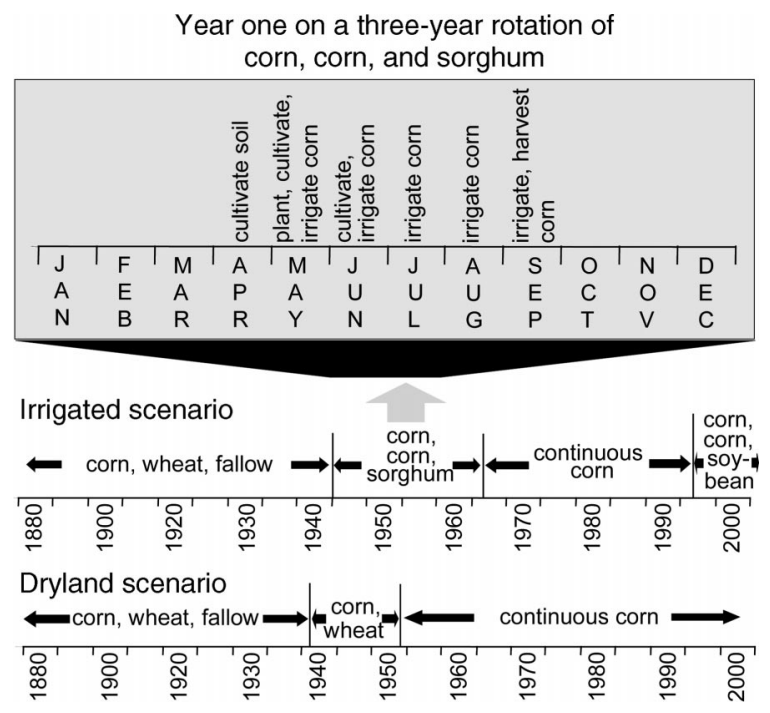

FIG. 4. Historical changes in the crop rotations and schedule file for irrigated and dryland cropping in Hamilton, Nebraska.

used the histories to tell us what crop rotations were predominant at different times, and how farming practices changed over time. Generally speaking, dryland cropping rotations were the first, beginning after the grasslands were plowed out for cultivation.

As an example, Fig. 4 shows the dominant crop rotations for dryland and irrigated agriculture in Hamilton County, Nebraska. In order to make the CENTURY model perform in a satisfactory way, all the models were started in the year 0 and were run with stable, moderately grazed grassland until at least 1880 . The dryland system used a corn-wheat-fallow rotation from 1880 to 1940 , a corn-wheat rotation from 1940 to 1950 , and continuous dryland corn from 1950 to 2000. The irrigated schedule file used the same schedule as dryland (corn-wheat-fallow) prior to 1940 because there was essentially no irrigation prior to 1940 and land that was moved into irrigation came from cultivated dryland agriculture. Irrigated land used a corn-corn-sorghum rotation from 1940 to 1960, a continuous corn rotation from 1960 to 1990, and a corncorn-soybean rotation after 1990. Irrigated land added after 1940 used the dryland schedule file until the start of irrigation, and the appropriate irrigated schedule file after irrigation began. For CRP land, we used the dryland schedule file until 1987 and then started a grassland that was not grazed or fertilized. The grassland schedule file assumed that there was moderate grazing during the whole model run (0-2000).

Fig. 4 shows the information required to build a CENTURY schedule file: For each month of each simulation run, the user needs to specify a detailed landuse and land-management record. For example, during the first year of the irrigated corn-corn-sorghum rotation, the soil is cultivated in April, planted with corn, 
TABLE 1. Historical changes in area in grassland, dryland, cropping, irrigated cropping, and Conservation Reserve Program (CRP) for Hamilton County, Nebraska, USA, with the areaweighted percentage for each model run.

\begin{tabular}{|c|c|c|c|c|c|c|}
\hline \multirow[b]{2}{*}{ Year } & \multicolumn{2}{|c|}{ Dryland } & \multicolumn{2}{|c|}{ Irrigated } & \multirow{2}{*}{$\begin{array}{l}\text { CRP } \\
\text { area } \\
\text { (ha) } \dagger\end{array}$} & \multirow[b]{2}{*}{$\begin{array}{l}\text { Grassland } \\
\text { area (ha) } \dagger\end{array}$} \\
\hline & Area (ha) & $\begin{array}{c}\text { Weighted } \\
\text { percentage }\end{array}$ & Area (ha) & $\begin{array}{c}\text { Weighted } \\
\text { percentage }\end{array}$ & & \\
\hline 1880 & 45668 & 6.82 & 0 & 0 & 0 & 93286 \\
\hline 1890 & 91969 & 6.92 & 0 & 0 & 0 & 46985 \\
\hline 1900 & 107138 & 2.27 & 0 & 0 & 0 & 31816 \\
\hline 1910 & 107138 & 0.00 & 0 & 0 & 0 & 31816 \\
\hline 1920 & 108206 & 0.16 & 0 & 0 & 0 & 30747 \\
\hline 1925 & 109938 & 0.26 & 0 & 0 & 0 & 29016 \\
\hline 1930 & 110998 & 0.16 & 0 & 0 & 0 & 27956 \\
\hline 1935 & 114160 & 0.47 & 0 & 0 & 0 & 24794 \\
\hline 1940 & 114160 & 0.00 & 2755 & 1.98 & 0 & 24794 \\
\hline 1945 & 115091 & 0.14 & 5510 & 1.98 & 0 & 23862 \\
\hline 1950 & 106827 & 0.00 & 8265 & 1.98 & 0 & 23862 \\
\hline 1954 & 99768 & 0.00 & 15323 & 5.08 & 0 & 23862 \\
\hline 1959 & 72001 & 0.06 & 43468 & 20.25 & 0 & 23485 \\
\hline 1964 & 72512 & 0.20 & 44298 & 0.60 & 0 & 22144 \\
\hline 1969 & 63251 & 0.23 & 55074 & 7.76 & 0 & 20629 \\
\hline 1974 & 48543 & 0.27 & 71560 & 11.86 & 0 & 18852 \\
\hline 1978 & 38370 & 0.75 & 86753 & 10.93 & 0 & 13830 \\
\hline 1982 & 38370 & 0.00 & 86753 & 0.00 & 0 & 13830 \\
\hline 1987 & 39344 & 0.30 & 86753 & 0.00 & 611 & 11840 \\
\hline 1992 & 39344 & 0.00 & 87159 & 0.29 & 611 & 11840 \\
\hline 1997 & 39344 & 0.00 & 96208 & 6.51 & 611 & 11840 \\
\hline
\end{tabular}

$\dagger$ Area-weighted percentages for the grassland and CRP runs were $0.44 \%$ and $11.69 \%$, respectively.

and cultivated and irrigated in May, cultivated and irrigated in June, irrigated in July and August, and harvested in September. Each of the four counties has its own schedule files for the major land-use patterns for the historically dominant crop rotations in each region. An important difference between the four counties is that, for Pawnee and Hamilton, the irrigated land came from dryland, while for Hockley, the irrigated land came from uncultivated grassland. There was negligible irrigation in Ramsey County, North Dakota.

For this project, we undertook a separate CENTURY model run for each area of land that was plowed out for dryland agriculture or was added to irrigated agriculture. The area of land added during a given time period will be the weight factor used to calculate county average level carbon and $\mathrm{N}$ mineralization rates. Each area of land added to irrigated and dryland agriculture has its own schedule file representing the unique history for that land. For example, dryland agricultural land converted in 1920 from grassland uses a composite schedule file including the grassland schedule information until 1920 and the dryland schedule information from 1920 to 2000. Dryland agricultural land converted in 1930 from grassland would use grassland schedule information until 1930, and dryland schedule information from 1930 to 2000.

Land that underwent two transitions adds more complexity, and we responded with another simplification in order to reduce the number of model runs and reflect the limitations of the data. We assumed (as it is not possible to know the exact time) that the first transition of land converting from grassland to dryland cropping, and then later to irrigated cropping, occurred when $50 \%$ of the land converted to dryland agriculture. In our Hamilton County, Nebraska, example, land in dryland cropping that converted to irrigated land in 1970 would use grassland schedule information until 1890 (the date when $50 \%$ of the land that would eventually be in dryland agriculture had been plowed out from native grasslands), and would then use dryland schedule information from 1890 until 1970, finishing with the irrigated schedule information from 1970 to 2000. We also did not represent land-use transitions where irrigated land went to dryland or pasture, nor where dryland cropping systems were transformed to grasslands. These systems were not represented because more detailed time series of photographic and remote sensing land-use data are needed to evaluate these land-use transfers.

\section{Summarizing the model runs}

Once the model runs were completed, we summed the weighted results. Table 1 is the land-use history for Hamilton County, Nebraska. Between 1870 and 1880, the first settlers occupied the land, plowing up the grassland and planting dryland wheat. By 1890, they had plowed and planted more than one-fourth of the land in the county, and more than half of the land that eventually would go into dryland cropping. By 1940, they gradually added land to the dryland base, with the last dryland cropping area added during the first half of the 1930s. Beginning with the 1940 agricultural cen- 
sus, we see irrigated acreage added, with most in place by 1978 . The last significant land-use change leads to land coming out of dryland farming and going into the CRP in the 1980s and 1990s. A separate model run is set up for each time that grassland is converted to irrigated or dryland cropping with 27 runs set up for Hamilton County, Nebraska. Weight factors for each run are shown in Table 1; each is the fraction of the total area in the county represented by a single model run. This history can be reduced to these four types of model-building scenarios: (1) Some land (11.7\%) stays in grassland for the entire history of the county (one model run); (2) some land (18.9\%) begins as grassland, and between 1880 and 1935 is gradually converted to dry cropland, where it stays until 2000 (14 model runs); (3) some land $(69.0 \%)$ begins as grassland, is converted to dry cropland, and between 1950 and 1977 is gradually converted to irrigated cropland, where it stays (11 model runs); and (4) some land $(0.4 \%)$ begins as grassland, is converted in the 1880 s to dry cropland, and is reconverted in 1987 to CRP land (one model run).

\section{Model Results}

This section describes the results from the model simulations for the four counties in the Great Plains. The results are set up to demonstrate: (1) the impact of the timing of plow-out, and (2) the system's sensitivity to including the dominant cropping systems. Model results will focus on the impact of these changes on the total system carbon and soil nitrogen mineralization rates. The soil nitrogen mineralization rate is a good index of soil fertility since availability of soil nitrogen is one of the primary factors limiting plant production. Most agricultural systems in the United States currently add fertilizer to achieve near-maximum plant production rates. The model runs demonstrate the potential errors possible in estimating current levels of $\mathrm{N}$ mineralization and soil carbon levels as a function of the number of agricultural systems included and the number of computer runs used to represent plow-out dates for irrigated and dryland agriculture.

Fig. 5 shows the impact of different plow-out dates (1890-1969) on the soil carbon and $\mathrm{N}$ mineralization for dryland agriculture in Pawnee, Kansas. The results show that soil carbon increases (Fig. 5a) for a few years following plow-out (addition of dead grass roots to the soil), and then drops by $50 \%$ during the next 30 years. Another $10-15 \%$ of the soil carbon is lost from 30 to 60 years after cultivation started. This same pattern of carbon loss is observed for all of the different dates when plow-out is initiated. The results show that year 2000 soil carbon levels are lowest for the 1890 plowout run and are progressively higher when the plowout date is later (and time period in cultivation is shorter). This suggests that year 2000 soil carbon levels will be overestimated if the assumed plow-out date is later than the observed plow-out date and underestimated if it is earlier. However, differences in 2000 soil carbon
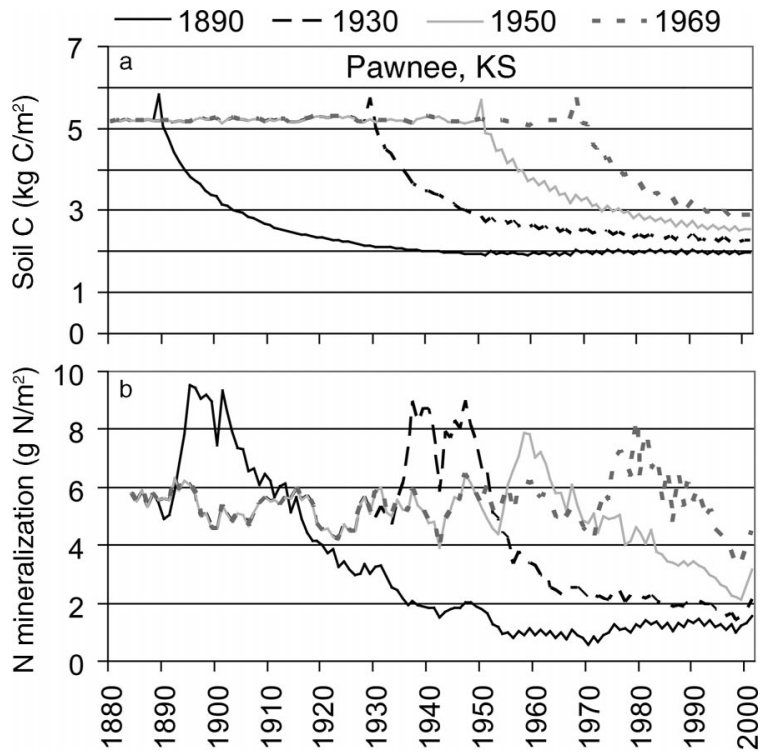

FIG. 5. CENTURY model-simulated (a) soil carbon levels and (b) soil nitrogen mineralization rates for a dryland cropping system in Pawnee, Kansas (KS), where cultivation of the native grassland started in 1890, 1930, 1950, and 1969.

levels are $<300 \mathrm{~g} \mathrm{C} / \mathrm{m}^{2}$ for the plow-out dates prior to 1950, suggesting that errors associated with estimating plow-out dates prior to 1950 are relatively minor. The results from dryland agriculture in Pawnee, Kansas, are similar to the results from the other three Great Plains counties (results not shown).

The results for the time series of $\mathrm{N}$ mineralization (Fig. 5b) as a function of time since plow-out (18901969) show that $\mathrm{N}$ mineralization increases rapidly following plow-out and stays high for the next 10-15 years. Nitrogen mineralization starts to decrease after 15 years of cultivation reaching values that are $15 \%$ of initial $\mathrm{N}$ mineralization rates after 60 years of cultivation. The initial increase of $\mathrm{N}$ mineralization occurs because of the release of $\mathrm{N}$ associated with the rapid loss of soil carbon during the first 10-30 years of cultivation. Results from the different plow-out dates show a similar pattern. The $\mathrm{N}$ mineralization rates in 2000 are the lowest for the 1890 plow-out run, but become progressively higher as the date of plow-out gets later, and are quite similar for plow-out dates $>50$ years ago. These results suggest that $2000 \mathrm{~N}$ mineralization rates will be overestimated if the assumed date of plow-out is later than the actual plow-out date, and that errors associated with estimating $2000 \mathrm{~N}$ mineralization will be minimal if the time of plow-out is $>50$ years ago.

The impact of starting irrigation at different dates on soil carbon and $\mathrm{N}$ mineralization was evaluated for Pawnee, Kansas, where we assumed that irrigated cropping will take place on land that has previously been cultivated using dryland agriculture techniques. The results (Fig. 6) show that irrigation will cause soil car- 

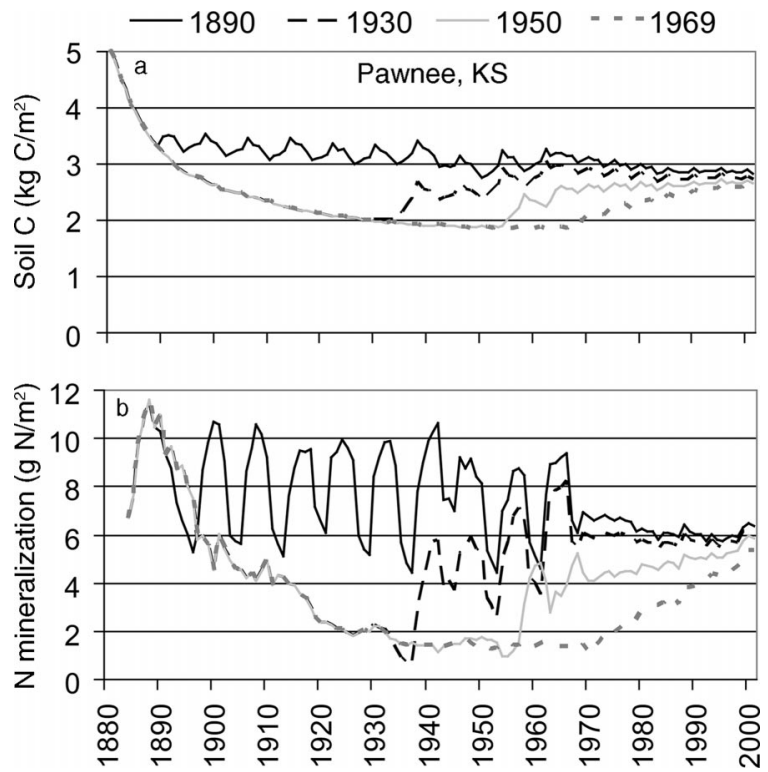

FIG. 6. CENTURY model-simulated (a) soil carbon levels and (b) soil nitrogen mineralization rates for irrigated cropping systems in Pawnee, Kansas (KS), where cultivation started in 1890, 1930, 1950, and 1969.

bon to increase relative to values at the beginning of irrigation if it is started later than 1900, that the different runs approach a new equilibrium soil carbon level of $2800 \mathrm{~g} \mathrm{C}^{2} \mathrm{~m}^{2}$, and that the simulated 2000 soil carbon levels are similar for runs where irrigation was started as late as 1960 . The simulated increases in soil carbon occur because the irrigated agriculture uses a higher production corn/alfalfa crop rotation that adds substantially more carbon to the soil than dryland crop rotations. These results suggest that errors in estimating current soil $\mathrm{C}$ levels will be minimal if irrigated agriculture starts before 1960 and that the irrigated corn/ alfalfa rotation approaches a new equilibrium soil carbon level quite rapidly (most of the increase occurs after the first 30 years of initiating the crop rotation). The results are similar to the results one gets by starting irrigation at different times for the Nebraska county, which uses a similar corn/alfalfa rotation. The model results suggest that $\sim 800 \mathrm{~g} \mathrm{C} / \mathrm{m}^{2}$ has been stored in the soil after initiation of irrigated agriculture in the 1960s.

The results for $\mathrm{N}$ mineralization show a pattern similar to those for soil carbon, with near equilibrium levels of $\sim 6 \mathrm{~g} \mathrm{~N} \cdot \mathrm{m}^{-2} \cdot \mathrm{yr}^{-1}$. The current values of $\mathrm{N}$ mineralization rates are similar for runs where the irrigation crop rotation was started before 1960 . Increased $\mathrm{N}$ mineralization results from nitrogen fixation associated with the alfalfa crop and nitrogen fertilizer additions to the corn crop after 1960. These results suggest that errors associated with estimating current $\mathrm{N}$ mineralization rates will be minimal if the irrigated crop rotation started prior to 1960 .
Cotton is the main crop in Hockley, Texas, where both irrigated and dryland cotton are grown. The landuse data (Fig. 3) show that irrigated land in Hockley came from grassland soils that had not previously been cultivated. This contrasts with the Nebraska county, where irrigation was started on land that had been cultivated using dryland agriculture. Results (Fig. 7) show that the commencement of irrigated farming causes a big decrease in soil $\mathrm{C}$, with most of the decreases in soil $\mathrm{C}$ coming during the first 20 years. The results for the dryland cotton system (not shown) are similar to their irrigated counterpart, except that soil carbon levels decrease more rapidly with the irrigated system and approach lower levels of soil carbon with the irrigated system (contrasting increase with corn/alfalfa irrigation). The large losses of soil carbon occur because the cotton system puts relatively small amounts of carbon back into the soil, and the wetter soil associated with irrigation enhances the carbon loss by increasing the decomposition rate in these warmer regions of the Great Plains (wetter soils have substantially higher decomposition rates). The results for both the irrigated and dryland cotton rotations show that soil carbon levels in 2000 are fairly similar (within $400 \mathrm{~g} \mathrm{C} / \mathrm{m}^{2}$ ) for runs where initiation of cultivation started before 1970 .

Results for Hockley, Texas, show that $\mathrm{N}$ mineralization rates increase rapidly (for 10 years) following initiation of irrigated agriculture, decline for the next 20 years, and then reach an equilibrium at $\sim 75 \%$ of the rates for the undisturbed grassland. The $\mathrm{N}$ mineralization rates for 2000 are quite similar for all of the runs where cultivation was started prior to 1970 . The relatively high $\mathrm{N}$ mineralization rates after the commencement of irrigated cotton agriculture result from


FIG. 7. Simulated (a) soil carbon levels and (b) soil nitrogen mineralization rates for an irrigated cropping system in Hockley, Texas (TX), where cultivation started in 1910, 1930, 1950, and 1969. 


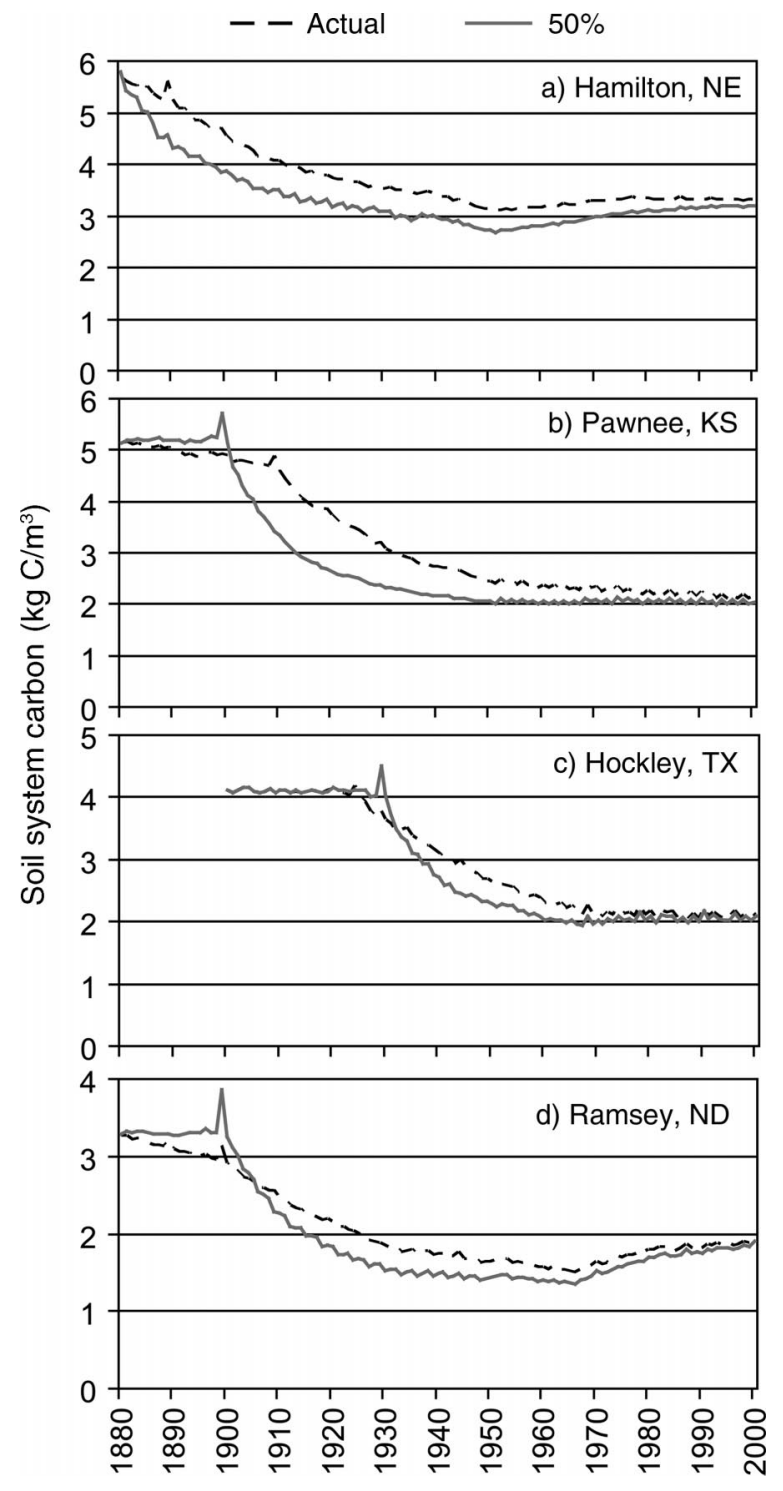

FIG. 8. System carbon levels for a single-model run that started when $50 \%$ of dryland cropping occurred compared with the weighted average of multiple-model runs that represent the actual timing of dryland cultivation (actual) in (a) Hamilton, Nebraska (NE), (b) Pawnee, Kansas (KS), (c) Hockley, Texas (TX), and (d) Ramsey, North Dakota (ND).

the addition of $\mathrm{N}$ fertilizer to the cotton rotation after 1940 (30-70 $\left.\mathrm{gm} \mathrm{N} \cdot \mathrm{ha}^{-1} \cdot \mathrm{yr}^{-1}\right)$. Clearly these results demonstrate that errors in estimating the starting date for the irrigated cotton system will have little impact on current $\mathrm{N}$ mineralization rates if it began before 1970.

Fig. 8 shows the soil $\mathrm{C}$ levels obtained when it was assumed that dryland cultivation started when $50 \%$ of the land was cultivated compared with soil $\mathrm{C}$ levels obtained by using multiple computer runs to represent the observed cultivation dates. Fig. 3 shows that it generally took 20-40 years for most of the grassland area to be converted to dryland agriculture after cultivation began in Great Plains counties. A set of runs that represent the actual times when grasslands were cultivated were performed, and the results were weighted by the area that was cultivated at a given time for each of the counties (Fig. 8). We will refer to the weighted average soil carbon levels as the actual soil carbon level; in contrast to the 50\% run, which represents a single run that imposes the change at the time when $50 \%$ of the change had taken place. The results for all of the counties show that the $50 \%$ run can be quite different from the actual soil carbon level for up to 60 years after initiation of dryland cultivation. The $50 \%$ run is quite similar to the actual soil carbon level in 2000, and there is generally little difference between the actual carbon level and the $50 \%$ run after 60 years of cultivation. These results confirm the conclusion from the previous results (Figs. 5, 6, and 7) showing relatively small differences between soil carbon and $\mathrm{N}$ mineralization rates for computer model runs when cultivation started $>50$ years ago.

We also set up model runs to evaluate the sensitivity of county-level total system carbon to the inclusion of the different major land uses in the county. The major agriculture systems in our Great Plains counties include dryland agriculture, irrigated agriculture, rangeland, and CRP land. We tested the assumption that all of the county land could be represented by four alternatives: the dominant agriculture land use (one land use for all country land), the top two agricultural land uses, the top three agricultural land uses, and the top four agricultural land uses. Fig. 9 shows the comparison of the total system carbon at the county level (all four counties) evaluated with the different assumptions about the number of land uses. With all of these runs we assumed that initiation of cultivation or irrigation would start after $50 \%$ of the land conversion happened. The results show that including one or two of the major land uses can result in significant differences (500 g $\mathrm{C} / \mathrm{m}^{2}$ difference for Pawnee, Kansas) from the best estimate of total system carbon (all land uses considered), while including three of the four land uses has soil $\mathrm{C}$ levels similar to the four-land-use runs (lines for the three- and four-land-use runs are overlapped on the graphs). In all the counties, CRP has the smallest fraction of land compared to other land uses $(<15 \%$ of the land area). This explains why including CRP as the fourth land use has little impact on total county system carbon. The results from the CRP land (not shown) for the different counties show that soil carbon levels were increased by $20-50 \mathrm{~g} \mathrm{C} \cdot \mathrm{m}^{-2} \cdot \mathrm{yr}^{-1}$ during the first 10 years, and soil $\mathrm{N}$ mineralization rates were only increased slightly $(<5 \%)$.

Table 2 shows a comparison of system-level carbon and soil $\mathrm{N}$ mineralization in the year 2000 derived by including different combinations of the dominant land uses. The results show that using only the dominant land use can result in significant differences in year 


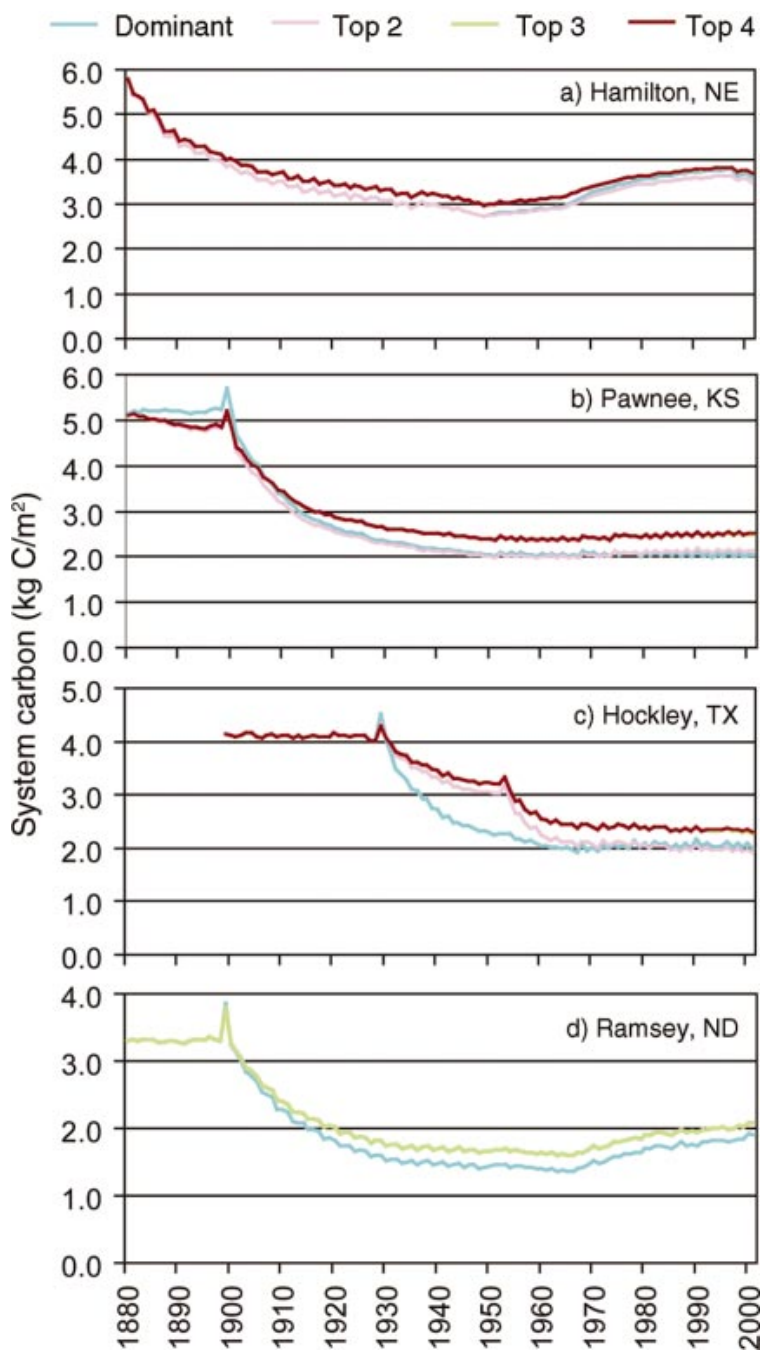

FIG. 9. Comparison of the simulated county-level system carbon for the model runs that represent the county using the dominant land use, the top two, the top three, and the four dominant land uses for (a) Hamilton, Nebraska (NE), (b) Pawnee, Kansas (KS), (c) Hockley, Texas (TX), and (d) Ramsey, North Dakota (ND). The land-use patterns are different for each of the counties. The actual land uses included for each county are shown in Table 2 .

2000 system carbon and $\mathrm{N}$ mineralization, when compared to the best estimated values derived by using all of the land uses. The biggest error is for Pawnee, Kansas, while there is little difference for Hamilton, $\mathrm{Ne}$ braska. Table 2 also shows that year 2000 total system carbon and $\mathrm{N}$ mineralization derived by using the fourland-use runs (four model runs) are similar to countylevel values derived by using the actual timing of land conversion (all) for the dominant land uses (30-50 model runs depending on the county). These results indicate that substantial errors in year 2000 system carbon and $\mathrm{N}$ mineralization can result if only the dominant land use is used to represent the county dynamics, compared with using the three or four most important land uses. However, including the actual timing of conversion of land for different land uses has little impact on year 2000 values. The insensitivity of year 2000 system $\mathrm{C}$ and $\mathrm{N}$ mineralization to the detailed representation of timing of land-use conversions is consistent with the results in Fig. 8 and occurred from the fact that most of the major land-use conversions took place $>50$ years ago. A comparison of the year 2000 soil carbon levels for the runs with one, two, three, and four dominant land uses with the soil carbon levels in undisturbed grasslands shows that all of the runs do a reasonable job of representing the large carbon loss associated with introduction of agriculture and suggest that even using the simplest representation of land-use change correctly represents the major loss of soil carbon associated with agricultural land-use conversion.

\section{DISCUSSION}

The main objectives of this paper were to evaluate the impact of Great Plains historical land-use patterns on crop yields, soil carbon, and soil $\mathrm{N}$ mineralization for counties that represent the major land uses in the Great Plains. The paper demonstrates an approach for using observed changes in land use derived from the Agricultural Census Data to drive the CENTURY plant-soil ecosystem model. A set of computer simulations were also set up to evaluate the potential sensitivity of county average soil carbon and $\mathrm{N}$ mineralization rates to the degree of resolution used to represent the timing of plow-out of grasslands, initiation of irrigated agriculture in the $1960 \mathrm{~s}$, and the extent to which the major agricultural systems (e.g., dryland agriculture, grazing, irrigated agriculture, CRP) are represented in the model simulations.

The model results for dryland agriculture show a general pattern of large losses $(\sim 50 \%)$ of soil carbon during the first 50 years following plow-out of native grasslands with most of the carbon loss coming during the first 20-30 years. Soil $N$ mineralization follows a general pattern of increased $\mathrm{N}$ mineralization for $10-$ 20 years following plow-out of the grassland, and a sharp decrease 20-50 years after plow-out with the rates approaching $20 \%$ of grassland levels after 50 years of cultivation. These simulated patterns in soil carbon and $\mathrm{N}$ mineralization are consistent with numerous studies (Haas and Evans 1957, Rasmussen and Parton 1994), which show rapid losses of soil carbon following plow-out of grassland soils, stabilization of soil carbon levels at $50 \%$ of initial values after 50 years of cultivation, and substantial decreases in soil mineralization after 50 years of dryland cultivation. The high $\mathrm{N}$ mineralization rates following plow-out of grassland soils is consistent with the observation that $\mathrm{N}$ fertilizer responses are minimal for dryland wheat fields in the Great Plains that have been cultivated for $<30$ years (Greb et al. 1974, Metherell et al. 1995).

Land-use data from the Great Plains (Fig. 3) show that one of the major changes in land use during the 
TABLE 2. Comparison of total system carbon and county-level soil $\mathrm{N}$ mineralization in year 2000 for computer runs that only included the dominant land use, the top two, three, and four land uses.

\begin{tabular}{|c|c|c|c|c|c|c|}
\hline State & Grassland & Dominant $\dagger$ & $\begin{array}{l}\text { Top two } \\
\text { (irrigated, } \\
\text { dry) }\end{array}$ & $\begin{array}{l}\text { Top three } \\
\text { (irrigated, } \\
\text { dry, grass) }\end{array}$ & $\begin{array}{c}\text { Top four } \\
\text { (irrigated, } \\
\text { dry, } \\
\text { grass, CRP) }\end{array}$ & ALL \\
\hline \multicolumn{7}{|c|}{ Soil carbon $\left(\mathrm{g} \mathrm{C}^{2} \mathrm{~m}^{2}\right)$} \\
\hline Nebraska & 5676 & 3690 & 3568 & 3748 & 3830 & 3805 \\
\hline Kansas & 5114 & 2037 & 2131 & 2488 & 2505 & 2563 \\
\hline Texas & 4040 & 2094 & 1978 & 2322 & 2340 & 2448 \\
\hline North Dakota & 3346 & 1910 & 2086 & 2084 & NA & 2124 \\
\hline \multicolumn{7}{|c|}{ Net $\mathrm{N}$ mineralization $\left(\mathrm{g} \mathrm{N} \cdot \mathrm{m}^{-2} \cdot \mathrm{yr}^{-1}\right)$} \\
\hline Nebraska & 7.6 & 8.6 & 8.6 & 8.5 & 8.5 & 8.4 \\
\hline Kansas & 8.1 & 2.0 & 2.3 & 3.0 & 3.0 & 3.4 \\
\hline Texas & 5.4 & 4.2 & 4.1 & 4.4 & 4.2 & 4.3 \\
\hline North Dakota & 3.4 & 1.1 & 1.4 & 1.4 & NA & 1.5 \\
\hline
\end{tabular}

Notes: County-level system soil carbon and $\mathrm{N}$ mineralization in year 2000 derived by including all of the four dominant land uses (CRP, Conservation Reserve Program). The actual timing of conversion of land to dryland, irrigated, and CRP land uses is also presented (All). The undisturbed grassland soil carbon and $\mathrm{N}$ mineralization rates for year 2000 are also presented. Each county has a different set of dominant land-use patterns.

$\dagger$ The dominant land use is irrigated agriculture for Nebraska and dryland for Kansas, Texas, and North Dakota.

last 50 years has been the dramatic expansion of irrigated agriculture from 1960 to 1980 with over 2.7 million ha of irrigated land being added during that time period. In the northern and central Great Plains, corn and alfalfa are the major crops grown on the irrigated land, while cotton is the dominant crop grown in the southern Great Plains (Texas and Oklahoma). The landuse data suggest that most of the irrigated land in the northern and central Great Plains was land that had been previously cultivated using dryland agriculture. The model results (Figs. 2 and 7) from Pawnee and Hamilton Counties show that starting irrigated corn/ alfalfa rotations in the 1960 s resulted in substantial increases in crop yields, soil carbon levels, and soil $\mathrm{N}$ mineralization rates. Most of the increases in soil carbon and $\mathrm{N}$ mineralization occurred from 1970 to 1990 because of the large increases in the amount of carbon

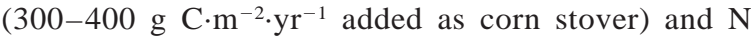
(100-150 $\mathrm{g} \mathrm{N} \cdot \mathrm{m}^{-2} \cdot \mathrm{yr}^{-1}$ fertilizer) added to the system with irrigated agriculture. Model results indicate that soil carbon levels increased by $>800 \mathrm{~g} \mathrm{C} / \mathrm{m}^{2}$ for irrigated land in Pawnee and Hamilton Counties from 1970 to 2000. Extrapolating these carbon accumulation rates to the 2.7 million ha of irrigated land added from 1960 to 1980 for the central and northern Great Plains would result in $21.3 \mathrm{Tg}$ of carbon sequestered in the soil.

The results from Hockley, Texas, for irrigated cropping stand in contrast to our results and show that irrigation of native grasslands results in large losses of soil carbon (2000 $\mathrm{g} \mathrm{C} / \mathrm{m}^{2}$ ) after 30 years of cultivating using a typical cotton rotation. The simulated losses of soil carbon are a result of the enhanced decomposition resulting from irrigation and relatively small inputs of plant carbon to the soil system $\left(100 \mathrm{~g} \mathrm{C} \cdot \mathrm{m}^{-2} \cdot \mathrm{yr}^{-1}\right)$ from the cotton rotation. This contrasts with the corn/alfalfa system in the central Great Plains where 400-500 g $\mathrm{C} \cdot \mathrm{m}^{-2} \cdot \mathrm{yr}^{-1}$ is added to the soil. Comparison of the carbon levels for the dryland and irrigated rotations (Figs. 5 and 8) in Hockley, Texas, show that soil carbon levels are lower for the irrigated runs in spite of the fact that carbon inputs are higher for the irrigated rotation and demonstrate the impact of irrigation on increasing soil decomposition rates. Combining the warmer air temperatures of the southern Great Plains with irrigation results in very high soil decomposition rates. This suggests that it is difficult to store carbon using irrigation rotations in the southern Great Plains unless inputs of plant residues are substantial. Extrapolating the simulated large losses of soil carbon from irrigated cotton cultivation in Hockley, Texas, to the 0.6 million ha of irrigated cotton land in the southern Great Plains would result in $12.1 \mathrm{Tg}$ of carbon lost from the soil (compared to $21.3 \mathrm{Tg}$ sequestered in irrigated soils in the central and northern Great Plains).

A series of computer runs were set up to determine the sensitivity of county-level total system carbon and soil $\mathrm{N}$ mineralization rates to the approaches used to represent land-use history in ecosystem models. A typical way to represent land-use history for a given county is to only represent the dominant land use and assume that the conversion of natural systems to agricultural systems occurs at a specified time (Schimel et al. 2000, Del Grosso et al. 2002a). Model results suggest that using a single model run (started when $50 \%$ of the county has been converted to cropland) to simulate conversion of grassland to cropland will result in substantially different estimates of soil carbon and $\mathrm{N}$ mineralization compared to a detailed representation of the timing of cropland conversion if the time period after conversion to cropland is $<50-60$ years. Detailed 
representation of the timing of cropland conversion has little impact on estimates of soil carbon and $\mathrm{N}$ mineralization rates if conversion of land to cropland started $>60$ years ago. The model results show that irrigated cropping rotations can reach near equilibrium levels of soil carbon and $\mathrm{N}$ mineralization rates sooner (20-30 years) than dryland crop rotations, and that $\mathrm{N}$ mineralization rates tend to converge more rapidly to equilibrium levels than soil carbon levels. The results suggest that uncertainty in estimating the timing of conversion of grasslands to crop land will have little impact on soil $\mathrm{C}$ and $\mathrm{N}$ mineralization rates if the initiation of cropland conversion started $>50-60$ years ago for dryland systems and 30-40 years ago for irrigated systems. Using only the dominant cropping pattern to represent a county can lead to substantial errors in simulating soil carbon and $\mathrm{N}$ mineralization rates; this suggests that all of the major cropping systems $(>80 \%$ of the land use) should be represented when simulating the ecosystem dynamics of a county. Simulation results indicate that the ecosystem dynamics of the four Great Plains counties studied here could be well represented by using four dominant crop rotations to represent the major land-use patterns in each county (e.g., grasslands, dryland crops, irrigated crops, CRP land) and start the timing of major land-use conversions when $50 \%$ of the land has been converted from one land use to another. Our results suggest that the simulated total carbon loss due to cultivation of Great Plains' soils in year 2000 is relatively insensitive to assumptions about when cultivation started; however, the time series of carbon loss during the last 150 years is sensitive to assumptions about when cultivation started. The results show (Fig. 6) that most of the carbon loss due to cultivation occurred during the 50 years following initiation of cultivation. Thus, studies that are interested in evaluating the time series of carbon loss from land-use change need to know the date when cultivation of native ecosystems starts and note that most of the landuse conversion will occur during the 30-40 year period following the initiation of cultivation (see Fig. 3).

This paper has demonstrated that the U.S. Agricultural Census land-use data are quite useful for showing the major historical changes in agricultural land-use practices (e.g., major expansion of irrigated land from 1960 to 1980); however, the data is not as definitive for determining prior land use that was converted to new land use (e.g., expansive irrigation in the 1960s). The results from the modeling effort have demonstrated that the purpose of the initial land use before it was converted to agricultural land can make a difference. For example, Fig. 6 shows that the initial soil carbon and $\mathrm{N}$ mineralization rates for dry agricultural land converted to irrigated land would be much lower compared to the initial rates when native grassland is converted to irrigated land. The only way to determine the land-use conversions for a specific land area is to use historical remote sensing or photographic data sets.
Clearly, the combination of the U.S. Agricultural Census Data and historical remote sensing land-use and photographic data is an approach that should be used to determine the dominant patterns for agricultural land-use transitions.

\section{ACKNOWLEDGMENTS}

The research for this paper was supported by the USA Environmental Protection Agency (EPA Project no. TGC04), the National Science Foundation Shortgrass Steppe LTER Project (no. DEB 0217631), the National Institute of Child Health and Human Development (Project no. 1 R01 HD33554), and through funds provided by the Cooperative State Research, Education, and Extension Service, USA Department of Agriculture (Agreement no. 2001-38700-11092), and to the Consortium for Agricultural Soils Mitigation of Greenhouse Gases (CASMGS). This material is based upon work supported by the Cooperative State Research, Education, and Extension Service, USDA, under Agreement no. 2001-38700-11092.

\section{Literature Cited}

Alexander, R. B., and R. A. Smith. 1990. County-level estimates of nitrogen and phosphorous fertilizer use in the United States, 1945-1985. Open File Report 90-130. USGS, Washington, D.C., USA. 〈http://water.usgs.gov/ pubs/ofr/ofr90130/cty_fert.txt>

Anonymous. 1924. Fertilizer used on cotton, 1923-1924. Table 753 from Miscellaneous Agricultural Statistics. Page 1171 in 1924 Yearbook of the Department of Agriculture. Government Printing Office, Washington, D.C., USA.

Bogue, A. G. 1963. From prairie to corn belt: farming on the Illinois and Iowa prairies in the nineteenth century. University of Chicago Press, Chicago, Illinois, USA.

Bonnen, C. A., and F. F. Elliott. 1931. Type of farming areas in Texas. Texas Agricultural Experiment Station Bulletin Number 427. Agricultural and Mechanical College of Texas, College Station, Texas, USA.

Bonnen, C. A., and R. H. Rogers. 1928. Profitable farming systems for the intensive spring wheat area in South Dakota. Farm Economics Department Bulletin 235. Agricultural Experiment Station, South Dakota State College of Agriculture and Mechanic Arts, Brookings, South Dakota, USA.

Brenner, J., K. Paustian, G. Buhm, J. Cipra, M. Easter, R. Foulk, K. Killian, R. Moore, J. Schuler, P. Smith, and S. Williams. 2002. Quantifying the change in greenhouse gas emissions due to natural resource conservation practice application in Nebraska. Colorado State University Natural Resource Ecology Laboratory and USDA Natural Resources Conservation Services, Fort Collins, Colorado, USA.

Briggs, L. J., and J. O. Belz. 1910. Dry farming in relation to rainfall and evaporation. USDA Bureau of Plant Industry Bulletin 188. Government Printing Office, Washington, D.C., USA.

Brooks, W. P. 1901. Agriculture. Volume II: manures, fertilizers and farm crops, including green manuring and crop rotation. Home Correspondence School, King-Richardson Publishers, Springfield, Massachusetts, USA.

Carleton, M. A. 1914. Hard wheat winning their way. Yearbook of the Department of Agriculture. Government Printing Office, Washington, D.C., USA.

Chilcott, E. C. 1907. Dry-land farming in the Great Plains area. Pages 451-468 in Yearbook of the Department of Agriculture. Government Printing Office, Washington, D.C., USA.

Chilcott, E. C. 1910. A study of cultivation methods and crop rotations for the Great Plains area. USDA Bureau of Plant Industry Bulletin Number 187. Government Printing Office, Washington, D.C., USA. 
Clark, J. M. 1904. Potato culture near Greeley, Colorado. Pages 311-322 in Yearbook of the Department of Agriculture. Government Printing Office, Washington, D.C. USA.

Cochrane, W. W. 1993. The development of American agriculture: a historical analysis. Second edition. University of Minnesota Press, Minneapolis, Minnesota, USA.

CTIC [Conservation Technology Information Center]. 1998. 1998 Crop residue management executive summary. CTIC, West Lafayette, Indiana, USA. 〈http://www.ctic.purdue edu/Core4/CT/CT.html $\rangle$

Del Grosso, S. J., D. S. Ojima, W. J. Parton, A. R. Mosier, and G. A. Peterson. 2002a. Regional assessment of net greenhouse gas fluxes from agricultural soils in the USA Great Plains under current and improved management. Pages 469-474 in J. van Ham, A. P. M. Baede, R. Guicherit, and J. G. F. M. Williams-Jacobs, editors. Proceedings of the Third International Symposium on Non- $\mathrm{CO}_{2}$ Greenhouse Gases. Millpress, Rotterdam, The Netherlands.

Del Grosso, S. J., D. S. Ojima, W. J. Parton, A. R. Mosier, G. A. Peterson, and D. S. Schimel. 2002b. Effects of dryland cropping intensification on SOM and greenhouse gas exchanges using the DAYCENT Ecosystem Model. Environmental Pollution 116:S75-S83.

Elliott, F. F. 1933. Types of farming in the United States. U.S. Department of Commerce, Government Printing Office, Washington, D.C., USA.

Elliott, F. F., and J. W. Tapp. 1928. Types of farming in North Dakota. USDA Technical Bulletin Number 102. Government Printing Office, Washington, D.C., USA.

Ellsworth, J. O. 1929. Types-of-farming in Oklahoma. Agricultural Experiment Station Bulletin Number 181 Oklahoma Agricultural and Mechanical College, Stillwater, Oklahoma, USA.

ERS [Economic Research Service]. 1994. Fertilizer use and price statistics. Stock Number 86012. ERS, USDA, Government Printing Office, Washington, D.C., USA. 〈http:// www.ers.usda.gov/data/archive/86012〉

ERS [Economic Research Service]. 2003. Ag chemical and production technology. ERS, USDA, Government Printing Office, Washington, D.C., USA. 〈http://www.ers.usda.gov

Fraps, G. S., and S. E. Asbury. 1931. Commercial fertilizers in 1930-31 and their uses. Agricultural Experiment Station Bulletin 434. Agricultural and Mechanical College of Texas, College Station, Texas, USA.

Georgeson, C. C., H. M. Cottrell, and W. Shelton. 1890. Experiments with oats. Experiment Station Bulletin Number 13. Kansas State Agricultural College, Manhattan, Kansas, USA.

Greb, B. W., D. E. Smika, N. P. Woodruff, and C. J. Whitfield. 1974. Summer fallow in the central Great Plains. Pages 51-85 in Conservation Research Report 17. USDA, Government Printing Office, Washington, D.C., USA.

Gutmann, M. P. 2000. Scaling and demographic issues in global change research. Climatic Change 44:377-391.

Gutmann, M. P., S. Pullum, G. A. Cunfer, and D. Hagen. 1998. Great Plains population and environment database. Version 1.0. User's guide. University of Texas Population Research Center, Austin, Texas, USA

Haas, H. J., and C. E. Evans. 1957. Nitrogen and carbon changes in Great Plains soils as influenced by cropping and soil treatments. Technical Bulletin 1164. USDA, Government Printing Office, Washington, D.C., USA.

Hardies, E. W., and A. N. Hume. 1927. Wheat in South Dakota. Agronomy Department Bulletin 222. Agricultural Experiment Station, South Dakota State College of Agriculture and Mechanical Arts, Brookings, South Dakota, USA.

Hargreaves, M. W. M. 1993. Dry farming in the northern Great Plains: years of readjustment, 1920-1990. University Press of Kansas, Lawrence, Kansas, USA.
Hodges, J. A., F. F. Elliott, and W. E. Grimes. 1930. Types of farming in Kansas. Agricultural Experiment Station Bulletin 251. Kansas State Agricultural College, Manhattan, Kansas, USA.

Holmes, G. K. 1903. Practices in crop rotation. Pages 519532 in 1902 Yearbook of the Department of Agriculture. Government Printing Office, Washington, D.C., USA.

Houghton, R. A. 1994. The worldwide extent of land-use change. BioScience 44:305-313.

Hurt, R. D. 1994. American agriculture: a brief history. Iowa State University Press, Ames, Iowa, USA.

Ibach, D. B., and J. R. Adams. 1967. Fertilizer use in the United States by crops and areas, 1964 estimates. Statistical Bulletin Number 408. USDA, Government Printing Office, Washington, D.C., USA.

Ibach, D. B., J. R. Adams, and E. I. Fox. 1964. Commercial fertilizer used on crops and pasture in the United States, 1959 estimates. Statistical Bulletin Number 348. USDA, Government Printing Office, Washington, D.C., USA.

Kelly, R. H., W. J. Parton, G. J. Crocker, P. R. Grace, J. Klir, M. Körschens, P. R. Poulton, and D. D. Richter. 1997. Simulating trends in soil organic carbon in long-term experiments using the Century Model. Geoderma 81:75-90.

Kezer, A. 1917. Dry farming in Colorado. Colorado State Board of Immigration, Denver, Colorado, USA.

Kifer, R. S., B. H. Hurt, and A. A. Thornbrough. 1940. The influence of technical progress on agricultural production. USDA Yearbook of Agriculture. Government Printing Office, Washington, D.C., USA.

Lander, C. H., and D. Moffitt. 1996. Nutrient use in cropland agriculture (commercial fertilizer and manure): nitrogen and phosphorous. Working Paper Number 104. USDA, Government Printing Office, Washington, D.C., USA. 〈http://www.nhq.nrcs.usda.gov/RCA_PAPERS/WP14/ wp14text.html

Leighty, C. E. 1938. Crop rotation. Pages 406-430 in Soils and men. 1938 Yearbook of Agriculture. USDA, Government Printing Office, Washington, D.C., USA.

Mathews, O. R., and J. S. Cole. 1938. Special dry-farming problems. Pages 679-692 in Soils and men. Yearbook of the Department of Agriculture. Government Printing Office, Washington, D.C., USA.

Matson, P. A., W. J. Parton, A. G. Power, and M. J. Swift. 1997. Agricultural intensification and ecosystem properties. Science 277:504-509.

Metherell, A. K., C. A. Cambardella, W. J. Parton, G. A. Peterson, L. A. Harding, and C. V. Cole. 1995. Simulation of soil organic matter dynamics in dryland wheat-fallow cropping systems. Pages 259-270 in R. Lal, J. Kimball, E. Levine, and B. A. Stewart, editors. Soil management and greenhouse effect. CRC Press, Boca Raton, Florida, USA.

Metherell, A. K., L. A. Harding, C. V. Cole, and W. J. Parton. 1993. CENTURY: soil organic matter model. Technical Document, Agroecosystems version 4.0. Great Plains Systems Research Unit, Tech Report Number 4. USDA-ARS, Fort Collins, Colorado, USA.

Miner, C. 1998. Harvesting the High Plains: John Kriss and the business of wheat farming, 1920-1950. University Press of Kansas, Lawrence, Kansas, USA.

Mitchell, J. E. 1988. Impacts of the Conservation Reserve Program in the Great Plains: Symposium Proceedings, September 16-18, 1987. USDA, General Technical Report RM-158. Rocky Mountain Forest and Range Experiment Station, Fort Collins, Colorado, USA.

NASS [National Agricultural Statistics Service]. 1995-1999. Published estimates database. NASS, USDA, Government Printing Office, Washington, D.C., USA. 〈http://www. nass.usda.gov:81/ipedb/>

NRI [Natural Resources Inventory]. 1997. Natural resources inventory. Natural Resources Conservation Service. USDA, 
Government Printing Office, Washington, D.C., USA. 〈http:// www.nhq.nrcs.usda.gov/MLH/nritest/nri_data.html〉

NRIAI [Natural Resources Inventory and Analysis Institute]. 2003. Regional budget and cost information. NRIAI. Natural Resources Conservation Service, USDA, Government Printing Office, Washington, D.C., USA. 〈http://waterhome. brc.tamus.edu/care/budgets/>

Ojima, D. S., W. J. Parton, D. S. Schimel, J. M. O. Scurlock, and T. G. F. Kittel. 1993. Modeling the effects of climatic and $\mathrm{CO}_{2}$ changes on grassland storage of soil C. Water, Air and Soil Pollution 70:643-657.

Palm, C. A., et al., editors. 2005. Slash-and-burn agriculture: the search for alternatives. Columbia University Press, New York, New York, USA.

Parton, W. J., M. P. Gutmann, and W. R. Travis. 2003. Historical land use change in eastern Colorado. Great Plains Research 13:97-125.

Parton, W. J., and P. E. Rasmussen. 1994. Long-term effects of crop management in wheat/fallow: II. CENTURY model simulations. Soil Science Society of America Journal 58 530-536.

Parton, W. J., J. M. O. Scurlock, D. S. Ojima, T. G. Gilmanov, R. J. Scholes, D. S. Schimel, T. Kirchner, J.-C. Menaut, T. Seastedt, E. Garcia Moya, A. Kamnalrut, and J. L. Kinyamario. 1993. Observations and modeling of biomass and soil organic matter dynamics for the grassland biome worldwide. Global Biogeochemical Cycles 7:785-809.

Paustian, K., W. J. Parton, and J. Persson. 1992. Modeling soil organic matter in organic-amended and nitrogen-fertilized long-term plots. Soil Science Society of America Journal 56:476-488.

Piper, C. V., et al. 1924. Hay. Pages 285-376 in Yearbook of Agriculture, 1924. Government Printing Office, Washington, D.C., USA.

Ramankutty, N., and J. A. Foley. 1999. Estimating historical changes in global land cover: croplands from 1700 to 1992. Global Biogeochemical Cycles 13:997-1027.

Rasmussen, P. E., and W. J. Parton. 1994. Long-term effects of residue management in wheat-fallow. I. Inputs, yield and organic soil matter. Soil Science Society of America Journal 58:523-530.

Rogers, R. H., and F. F. Elliott. 1929. Types of farming in South Dakota. Farm Economics Department Bulletin 238. Agricultural Experiment Station, South Dakota State College of Agricultural and mechanic Arts, Brookings, South Dakota, USA.

Ross, W. H., and A. L. Mehring. 1938. Mixed fertilizers. Pages 522-545 in Soils and men. Agricultural Yearbook 1938. USDA, Government Printing Office, Washington, D.C., USA.

Salter, R. M., and C. J. Schollenberger. 1938. Farm manure. Pages 445-461 in Soils and men. Agricultural Yearbook 1938. USDA, Government Printing Office, Washington, D.C., USA.

Schimel, D., et al. 2000. Contribution of increasing $\mathrm{CO}_{2}$ and climate to carbon storage by ecosystems in the United States. Science 287:2004-2006.

Sewell, M. C., and L. E. Call. 1925. Tillage investigations relating to wheat production. Technical Bulletin 18. Agricultural Experiment Station. Kansas State Agricultural College, Manhattan, Kansas, USA.

Shelton, E. M., H. M. Cottrell, and W. Shelton. 1889. First annual report of the Kansas Experiment Station, State Agricultural College, for the year 1888. Kansas Experiment Station, State Agricultural College, Manhattan, Kansas, USA.

Sisk, T. D., editor. 1998. Perspectives on the land-use history of North America: a context for understanding our changing environment. Biological Science Report USGS/BRD/BSR 1998-0003 (Revised September 1999). USGS, Biological Resources Division, Washington, D.C., USA.

Skinner, J. J. 1931. Fertilizers for cotton soils. Miscellaneous Publication Number 126. USDA, Government Printing Office, Washington, D.C., USA.

Smalley, H. R., R. H. Engle, and H. Willett. 1939. American fertilizer practices: second survey. National Fertilizer Association, Washington, D.C., USA.

Smith, C. B. 1912. Rotations in the Corn Belt. Pages 325336 in 1911 Yearbook of the Department of Agriculture. Government Printing Office, Washington, D.C., USA.

Spillman, W. J. 1902. Systems of farm management in the United States. Pages 343-364 in Yearbook of the Department of Agriculture. Government Printing Office, Washington, D.C., USA.

Spillman, W. J. 1905. Diversified farming in the Cotton Belt. Pages 193-218 in Yearbook of the Department of Agriculture. Government Printing Office, Washington, D.C., USA.

Spillman, W. J. 1908. Types of farming in the United States. Pages 351-366 in Yearbook of the Department of Agriculture. Government Printing Office, Washington, D.C., USA.

Steinel, A. T. 1926. History of agriculture in Colorado. State Agricultural College, Fort Collins, Colorado, USA.

Throckmorton, R. I., and F. L. Duley. 1935. Twenty years of soil fertility investigations. Kansas. Agricultural Experiment Station Technical Bulletin 40. Kansas State College of Agriculture and Applied Science, Manhattan, Kansas, USA.

USDA. 1938. Soil and men. Yearbook of agriculture 1938. USDA, Government Printing Office, Washington, D.C., USA.

USDA. 1946. Fertilizer sand lime in the United States. Miscellaneous Publication Number 586. USDA, Government Printing Office, Washington, D.C., USA.

USDA. 1954. Fertilizer use and crop yields in the United States. Fertilizer Work Group. Agricultural Handbook Number 68. USDA, Government Printing Office, Washington, D.C., USA.

USDA. 1966. Consumption of commercial fertilizers and primary plant nutrients in the United States, 1850-1964 and by states, 1945-1964. Statistical Reporting Service. Statistical Bulletin Number 375. USDA, Government Printing Office, Washington, D.C., USA.

USDA FSA [Farm Service Agency]. 2000. Conservation Reserve Program data set. Kansas City, Missouri, USA.

USDA SCS [Soil Conservation Service]. 1981. Land resource regions and major land resource areas of the United States. Agricultural Handbook 296. USDA SCS, Government Printing Office, Washington, D.C., USA. 〈http:// water.usgs.gov/GIS/metadata/usgswrd/mlra.html

von Trebra, R. L., and F. A. Wagner. 1932. Tillage practices for south-western Kansas. Agricultural Experiment Station Bulletin 262. Kansas State College of Agriculture and Applied Science. Manhattan, Kansas, USA.

Wallace, H. A., and E. N. Bressman. 1923. Corn and corn growing. Wallace Publishing, Des Moines, Iowa, USA.

Warren, J. A. 1911. Agriculture in the central part of the semiarid portion of the Great Plains. Bureau of Plant Industry Bulletin Number 215. USDA, Government Printing Office, Washington, D.C., USA.

Wooten, E. O. 1924. Dry farming in eastern Colorado: a study of 151 farms in Lincoln and Washington Counties. Farm year 1922: a preliminary report. Report Number 5241-30. USDA Bureau of Agricultural Economics, Government Printing Office, Washington, D.C., USA. 